Dept of Food Hygiene,

Animals Health Research Institute, Dokki, Giza.

\title{
TRACESS OF ALUMINIUM IN RAW MILK AND THE EFFECT OF BOILING OF MILK AND STORAGE IN THE ALUMINIUM UTENSILS
}

(With 2 Tables)

By

\section{EMAN I. EL-MOSSALAMI and SHIREEN M. NOSEIR}

(Received at 17/3/2009)

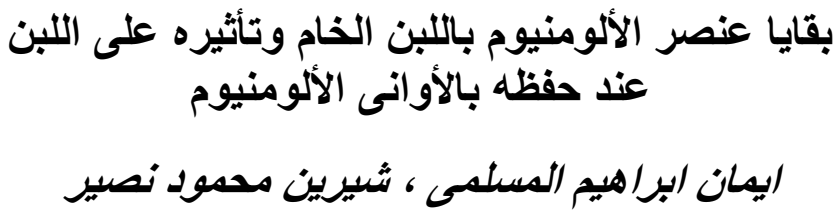

بعض الأبحاث ذكرت أنتقال عنصر الألومنيوم من اوانى الطهو الألومنيوم الى الطعام أثناء

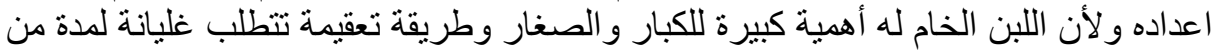

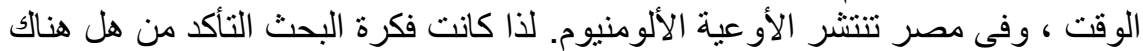

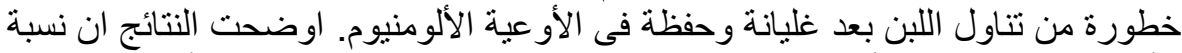

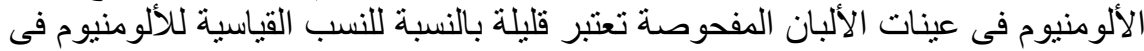

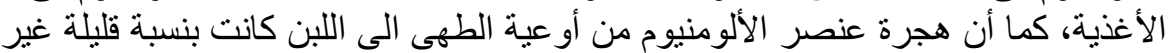

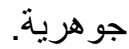

\section{SUMMARY}

The level of aluminium was evaluated in raw milk sold in markets and the effect of Kitchen aluminium utensils on aluminium content of milk during boiling and storing at $4^{\circ} \mathrm{C}$ for different periods, the amount of aluminium was determined by atomic absorption spectrophotometry. The aluminium concentration in raw milk samples ranged from 0.1 to 1.7 with a mean of $0.84 \mathrm{ppm}$, these values are below the tolerable daily intake $(1 \mathrm{mg} / \mathrm{kg}$ of body weight per day)which has been established by an international committee of experts under the auspices of the world Health Organization and the Food and Agricultural Organization of the united nation, the results showed that the increase in aluminium due to migration from aluminium and stainless steel utensils during boiling and storage of milk was relatively low.

Key words: Milk, aluminum, aluminum utensils 


\section{INTRUDUCTRION}

Environmental pollution represents a major problem in both developed and underdeveloped countries. Egypt is a country which suffers from high biosphere pollution (air, soil, and water). Many ecological changes occur in water as a result of human activities, including agricultural and municipal wastes (Atta, et al., 1997).

Aluminium is the third most abundant element in the lithosphere and the aluminium resources are considerable. During the last 100 years of industrialization, the importance of aluminium has become indispensable in many industrial areas, e.g. the packaging industry, as well as in daily life.

Aluminium compounds used as food additives are an additional source of this element in food in many countries. Such additives are not permitted. Food pollution with aluminium may, to some extent, be augmented by use of aluminium cutlery and kitchen utensils, equipments used in food industry, as well as packaging (Shaalan, 2002).

Many possible sources of aluminium intake by the human body exist, e.g. drugs, foods, drinking water and, industrial exposure. Food is the main route by which the normal daily intake of aluminium occurs. The total aluminium content arises from food containers such as cans, cookware, utensils and food wrappings. It has been established that cooking of acidic and low acidic foods in aluminium saucepans or foil causes leaching of the metal (Liukkonen- Lilja and Piepponen, 1992; Brunner, et al., 1999; Rajwanshi et al., 1999; Takeda et al., 1998 and 1999). Food manufactured and stored in aluminium cans, showed an increased aluminium content (Aikoh and Nishio, 1996; Rajwanshi et al., 1997; Seruga et al., 1997).

High levels of aluminium in foods can be attributed to chemical corrosion by acids or alkalis during boiling for short period in aluminium vessels, electrochemical corrosion when foods are left in contact with aluminium vessels for long period, acidic and salty food increasing concentration of complexing ions, (Mei and Yao 1994; Gramiccioni et al., 1996 and Shuping 1996).

Sensetivity of infants and children to the environmental contamination is more than that of adults, because the permeability of the gastrointestinal tract of infants is great, as protective mechanisms have not yet fully developed, to allow many of the substances in human mother's milk to systemically permeate the body of the infant. Unfortunately, the same lake of protection seriously impairs an infant 
who consumes infant formula, especially soy formulas, and bovine milk. Research work, indicates that aluminium concentrations in most cow's milk is 20 times greater than human breast milk $(5-20 \mathrm{mcg} / \mathrm{l})$ and 100 times greater in soy-based formulas (Pediatrics, 1986). In Dakahlia Governorate, Egypt, Maha Al-Ashmawy (2009) reported that, the aluminium content in examined bulk farm milk was ranged from 0.00284 to $0.00867 \mathrm{mg} / \mathrm{L}$, while in market milk reveal higher concentration ranging from 0.02113 to $0.18350 \mathrm{mg} / \mathrm{L}$.

Healthy adults are in zero balance for Al. The gastrointestinal tract excludes greater than $95 \%$ of diatery $\mathrm{Al}$, and kidney is the dominant organ for $\mathrm{Al}$ excretion. However, even with normal renal function, only 30-60\% of an Al load from parenteral nutrition is excreted in the urine, resulting in tissue accumulation of $\mathrm{Al}$. The risk for $\mathrm{Al}$ toxicity is greatest in infants with chronic renal insufficiency, recipients of long term parenteral nutrition, i.e., no gut barrier to Al loading, and preterm infants with low Al binding capacity. (Koo, and Kaplan, 1988)

Aluminium ions in human diet are non bio available from the small intestine because the hydrated charged ions are not able to penetrate the lipid protein membranes of the duodenal mucosa. But it can be assumed that at least part of the human dietary aluminium intake is in form of chelates with natural food components such as citric and lactic acids (Shuping, 1996). In the human body aluminium ions could inhibit different metabolism processes caused by competition reactions between aluminium and other ions such as calcium, magnesium or iron (Macdonald and Martin, 1988). Therefore, aluminium has been associated with several skeletal osteomalacia (Blumenthal and Posner, 1984; Boyce et al., 1982; Bushinsky, et al., 1995) and neurological disorders e.g Alzheimer's disease (Armstrong et al., 1996 and Lamb, 1995).

In recent years aluminium is responsible for another neurological disorder: encephalopathy or dialysis dementia (Alfrey, 1997; Meiri et al., 1992) in uremic patients on dialysis.

The extent of the increase of aluminium is dependent on factors such as temperature, $\mathrm{pH}$ value, duration of contact or heating, presence of sugar, organic acids, salt and other ions (Ranau et al., 2001).

The average daily intake of aluminium for adult men, women, 6-11 month old infants and 14-16 years old males is 8-9, 7, 0.7 and 11.5 $\mathrm{mg}$ /day respectively (Becker, et al., 1990). A tolerable daily intake (TDI) for aluminium of 1 milligram per kilogram of body weight per day has been established by an international committee of experts under the 
auspices of the World Health Organization and the Food and Agricultural Organization of the United Nations (Bureau of Chemical Safety, 2003).

Boiling of milk in aluminium utensils is common in Egypt, for sterilization of milk which is consider as an important food for infant and children. The aim of the present work is to measure the aluminium content of the raw milk and whether the boiling process in aluminium utensils leads to increase of its amount.

\section{MATERIALS and METHODS}

The experiment samples (raw cow milk) and commercial samples (10 raw milk samples) were obtained from Cairo Governorate, send to the laboratory and analyzed for their Al. content by wet oxidation method, (AOAC, 1990) using Perkins Elmer 2380 Atomic Absorption Spectrophotometer at wave length 309 temp. 2900-3000 $\mathrm{C}$ with nitrous oxide and acetylene.

Experiment samples were 3 samples of raw cow milk of weight $1000 \mathrm{gm}$, obtained from commercial dairy shops, each sample was divided into 3 portions, the first was examined as control, the second was boiled with stirring in aluminium pan for $10 \mathrm{~min}$., cooled, and stored at $4^{\circ} \mathrm{C}$ for $72 \mathrm{hr}$. and analyzed for their $\mathrm{AL}$. content at $0,24,36,48,72 \mathrm{hr}$. The third part was boiled with stirring in stainless pan for $10 \mathrm{~min}$., cooled, stored at $4^{\circ} \mathrm{C}$ for $72 \mathrm{hr}$ and analyzed for their $\mathrm{Al}$ content at $0,24,36,48,72 \mathrm{hr}$.

The aluminium utensils were rubbed with aluminium scourer until the metal shining appeared, cleaned with soap sponge, then washed with water as usual in Egyptian kitchens.

\section{RESULTS}

Table 1: Levels of aluminium content (ppm) in raw milk samples

\begin{tabular}{|l|l|l|l|}
\hline No. of samples & Mean & Min & Max \\
\hline 10 & 0.84 & 0.1 & 1.7 \\
\hline
\end{tabular}


Table 2: level of aluminium content (ppm) in raw milk* after boiling for $10 \mathrm{~min}$ and holding at $4^{\circ} \mathrm{C}$.

\begin{tabular}{|l|l|l|}
\hline Holding time & Milk in AL pan & Milk in steel pan \\
\hline 0 time & 1.58 & 1.50 \\
\hline $1^{\text {st }}$ day & 1.60 & 1.54 \\
\hline $2^{\text {nd }}$ day & 1.60 & 1.54 \\
\hline $3^{\text {rd }}$ day & 1.64 & 1.56 \\
\hline
\end{tabular}

*AL. content of milk before boiling was $1.50 \mathrm{ppm}$.

\section{DISCUSSION}

Table (1) showed the aluminium contents of raw milk samples in ppm wet weight. Regarding the body weight,present state of knowledge and the provisional tolerable daily intake of $1 \mathrm{mg} \mathrm{Al} / \mathrm{Kg}$ body weight per day of the World Health Organization 1989, there is no evident risk to the health of the consumer.

The results in Table (2) showed that the increase in aluminium content of raw milk because of the migration from cooking pans were relatively low.Nearly similar results were reported by Maha ALAshmawy (2009), this may be due to an invisible, protective outer layer of aluminium oxide forms immediately metallic aluminium is exposed to moist air. Macrae et al. (1997), revealed that dramatic affinity for oxygen, and the ability of the oxide so formed to bind firmly to the exposed metal, which affords aluminium its many diverse applications. Not only does this coating of oxide protect the surface of aluminium against further oxidation, but also protects the metal from reaction with many other chemicals. The oxide exhibits excellent resistance to corrosion by many inorganic and organic chemicals within a $\mathrm{pH}$ range of 4.5-9, but is susceptible to reaction with both acids and bases outside of this range. Gramiccioni et al. (1996) found that the increase in aluminium because of migration from cookware was relatively low with the highest release into acidic and salty foods.

\section{REFERENCES}

Aikoh, H. and Nishio, M.R. (1996): Aluminium content of various canned and bottled beverages. Bulletin of Enviromental Contamination and Toxicology, 56, 1-7. 
Al-Ashmawy Maha, A.M. (2009): Prevealence and Public Health significance of Alumium residues in milk and some dairy products. $6^{\text {th }}$ Int. Sci. Conf., Mansoura, 22-23 April, 497-509.

Alfrey, A.C. (1997): Dialysis encephalopathy. InYasui, M., Strong, M.J. Ota, K., Verity, M.A., Mineral and metal neurotoxicology. (pp. 127-136). CRC press Inc. AOAC. (1990): Official Method of Analysis, $15^{\text {th }}$. Ed. Assoc.of Official Analytic Chemistry, Washington, Dc.

Armstrong, R.A.; Wins per, S.J. and Blair, J.A. (1996): Aluminium and Alzheimer's disease: Review of possible pathogenic mechanisms Dementia, 7, 1-9.

Atta, M.B.; El-Sebaie, M.A. Noaman and Kassab, H.E. (1997): The effect of cooking on the content of heavy metals in fish (Tilapia nilotica). Food Chemistry. Vol. 58. No. 1-2pp. 1-4.

Becker, K.; Nollke, P.; Hermann-Kunz, E.; Krause, C.; Schenker, D. and Schultz, C. (1990): Umwelt-survey 1990/91 Band 111: 1m Auftrage des Bundesministeriums fur Umwelt Naturschutz und Reaktorsicherheit.

Blumenthal, N.C. and Posner, A.S. (1984): In vitro model of aluminium induced osteomalacia: inhibition of hydroxyapatite formation and growth. Calcified Tissue International, 36 439- 441.

Boyce, B.F.; Elder, H.Y.; Elliot, H.L.; Fogelman, I.; Fell, G.S.; Junors, B.J.; Beastall, G. and Boyle, I.T. (1982): Hypercalcaemic osteomalacia due to Aluminium toxicity. The Lancet, 2, 1009-1013.

Brunner, B.; Arnold, R. and Stolle, A. (1999): Ubergang Von aluminium auf Llebensmittel. Verwendung Von folien bei Kuchentechnischer Zubereitung Von Fisch und Fleisch. Fleischwirtschaft, 1/99. 110-112.

Bushinsky, D.A.; Sprague, S.M.; Hallegot, P.; Girod, C.; Chabala, J.M. and Levi-Setti, $R$. (1995): Effects of aluminium on bone surface ion composition. Journal of Bone and Mineral Research 10, 1988-1997.

Bureau of Chemical Safety (2003): Trace metal analysis- infant formula, Food directorate, Health products and food branch, Health Canada, February 5.

Gramiccioni, L.; Ingrao, G.; Milana, M.R.; Santaroni, P. and Tomassi, G. (1996): Aluminium levels in Italian diets and in selected foods from aluminium utensils. Food Additives and Contaminants 13 (7), 767. 
Koo, W.W. and Kaplan, L.A. (1988): Aluminium and bone disorders with specific reference to aluminium contamination of infant nutrients, Journal of the American College of Nutrient, Vol 7, Issue 3 199-214, Copyright (C) 1988 by American College of Nutrition.

Lamb, B.T. (1995): Making models for Alzheimer's disease. Nature Genetics, 9, 4-6.

Liukkonen-Lilja, H. and Piepponen, S. (1992): Leashing of aluminium from aluminium dishes and packages. Food Additives and Contaminants, 9, 213-223.

Macdonald, T.L. and Martin, K.B. (1988): Aluminium ion in biological systems. Trends Biochemical Science, 13, 15-19.

Macrae, R.; Robinson, R.K.; Sadler, M.J. (1997): Encyclopaedia of Food Science, Food Technology and Nutrition, Vol 3, 127. Academic Press Harcourt Brace Jovanovich, Publishers, London. San Diego. New York.

Mei, L. and Yao, T. (1994): Aluminium contamination of food from using aluminium ware. International J. Environ. Anal.Chem. 50 (1), a1.

Meiri, H.; Banin, E.; Roll, M. and Rousseau, A. (1992): Toxic effects of Aluminium on nerve cells and synaptic transmission. Progress in Neurobiology, 40, 89-121.

Pediatrics (1986): Aluminium toxicity in infants and children, Pediatrics, Vol. 78, p1150-1154. cited after copyright 1996 Leading Edge Research Group.

Rajwanshi, P.; Singh, V.; Gupta, M.K. and Dass, S. (1997): Leaching of aluminium from cook wares- a review. Enviromental Geochemistry and Health, 19, 1-18.

Rajwanshi, P.; Singh, V.; Gupta, M.K.; Shrivastav, R.; Subramanion, V.; Prakash, S. and Dass, S. (1999): Aluminium leaching from surrogate aluminium food containers under different $\mathrm{pH}$ and fluoride concentrations. Bulletin of Enviromental Contamination and Toxicology 63, 271-276.

Ranau, R.; Oehlenschlager, J. and Steinhart, H. (2001): Aluminium levels of fish fillets baked and grilled in aluminium foil. Food Chemistry 73, 1-6.

Seruga, M; Grgic, J.; Grgic, Z. and Seruga, B. (1997): Aluminium content of beers. Zeitschrift fur lebensmittel-Untersuchung und - Forschung, 204, 221-226. 
Shaalan, S.H. (2002): Effect of copper, zinc and vitamin E on aluminium toxicity. Egypt. J. Zool., 37: 111-124, December.

Shuping, B. (1996): A model describing the complexing effect in the leaching of aluminium from cooking utensils. Environ. Poll. 92(1), 85 .

Takeda, Y.; Kawamura, Y. and Yamada, T. (1998): Dissolution of aluminium from aluminium foils products in food- simulating solvents. Journal of the Food Hygienic Society of Japan, 39, 178-183.

Takeda, Y.; Kawamura, Y. and Yamada, T. (1999): Migration of aluminium from disposable aluminium foils vessels into foods. Journal of the Food Hygienic Society of Japan, 40, 172-177.

World Health Organization (1989): Toxicological evaluation of certain food additives and contaminants. Food Additives Series Vol. 24, 116- 117. University Press, Cambridge. 